\title{
Integration of research and nursing experiential learning: a case study
}

\author{
SCD Wright, D Tech Nursing \\ Department of Nursing, Tshwane University of Technology \\ I Benninghoff, B Cur Honours \\ Department of Nursing, Tshwane University of Technology
}

\section{Keywords:}

Nursing research, teaching, experiential nursing, nursing practica

\section{Correspondence address:}

\section{SCD Wright}

Senior lecturer

Department of Nursing

Tshwane University of Technology

Private bag $\times 680$,

Pretoria

OOO1

Tel : (012) 382-5470

Fax : (012) 382-5033

E-mail: wrightscd(âtut.ac.za

\section{Abstract: Curationis 30(1): 41-47}

Teaching research to undergraduates has it own challenges and involving undergraduates in research practical experience is just one of those challenges. As nursing students are in the process of becoming professional nurses, knowledge and skills in research are specific outcomes of the curriculum. One of the outcomes of the B Tech Nursing Science programme offered by the Tshwane University of Technology states that for the baccalaureate nursing programme include analysis, interpretation and utilisation of a range of research findings in scientific nursing and midwifery care as well as the development of a research protocol in a given context. In an effort to ensure that students would experience research as an essential part of their daily activities, an integrated approach is suggested whereby the nursing experiential learning opportunities are also research experiential learning opportunities. Using the integration strategy, research theory come 'alive' for the students. The integration approach is uncomplicated and transferable to any other discipline. The case study presented is the second year nursing students using school nursing experiential learning as a research project. The second year nursing students have a community focus during their second year and one of the experiential learning opportunities is school health nursing in a primary school in Tshwane. The results of the school health survey are presented. The students developed a health education intervention based on the research results.

\section{Abstrak}

Om voorgraadse studente te onderrig om navorsing te doen is nie sonder uitdagings nic, en een van daardie uitdagings is om geskikte leergeleenthede te skep. Die eis om navorsingskennis en vaardighede te kan demonstreer, word bepaal deur die vereistes om as verpleegkundige te kan registreer. Een van die uitkomste van die B Tech Verpleegwetenskappe kursus van Tshwane University of Technology beskryf die ontleding, interpretasie en gebruik van navorsingsresultate as ook die ontwikkeling van ' $n$ navorsingsprotokol in ' $n$ gegewe konteks. Aangesien die departement wil verseker dat verpleegkunde studente navorsing as " $n$ normale deel van hul dagtaak beskou, word ' $n$ geïntegreerde benadering waar ervaringsleer vir beide verpleging en navorsing aangewend word. Deur die gebruik van die geïntegreerde benadering, begin die navorsing lewendig raak vir die studente. Die benadering is eenvoudig en oordraagbaar na enige ander dissipline. "n Gevallestudie word voorgelê waar die tweedejaar verplecgstudente skool verpleging as 'n navorsingservaringsleer projek gebruik. In die tweede jaar van studie, is die fokus op die gemeenskap en skoolgesondheid in " $n$ laerskool in Tshwane is een van die leergeleenthede. Die resultate van die gesondheid van die leerders in die skool word voorgelê en bespreek. Die studente het ' $n$ gesondheidsbevorderingsprogram ontwikkel na aanleiding van die resultate van die navorsing. 


\section{Introduction}

"Nursing is a dynamic profession in a changing world." This statement is heard so often that it has almost lost it's meaning - it does however, represent a challenge to nurse educators in the preparation of nursing learners. Educators are charged with preparing nursing learners to cope with future problems - problems not yet encountered. Learners cannot be prepared for every eventuality encountered in practice. Learners need to be competent in the knowledge, skills, attitudes, and values necessary to deal with diverse situations in their professional lives. One of the competencies that will empower learners in doing so is doing and using research. Wilson (1992:18) emphasises this point in writing that the development of scientific knowledge as a foundation for safe, secure, scientifically based practice has been designated as a responsibility of all nurses.

Registered nurses in clinical positions rarely practise research, though research is regarded as one of the four pillarsclinical, management, education and research - of nursing. Thorpe and Smutko (1998:13) write that every nurse, regardless of educational preparation, should be involved in and benefit from nursing research. The research process should therefore be an integral part of nursing practice. This ideal is unfortunately far removed from reality. Problems regarding the education of research have been reported in literature for the past four decades. Integration of nursing theory, research and practice is a long-standing goal but it is well recognised that learners have difficulty in seeing the relevance of research in their future practice. Unless research findings are applied to practice, nursing research is little more than an 'ivory tower' exercise.

Teaching nursing research can be a challenging role for nurse educators. Even when the nurse educator is equipped with a large arsenal of teaching strategies designed to promote student interest; learners might still complete their studies without a basic understanding of research (Wisneski, 1998:135). Another problem that has been reported widely is the attitude towards research in undergraduate and postgraduate learners. Learners exhibit a negative attitude towards research and even the mention of research is met with resistance. Learners also complain that research has no value for their future roles as registered nurses. In most instances, research is done purely to obtain an academic qualification.

From experience in the Department of Nursing, Tshwane University of Technology, teaching research to post basic baccalaureate learners for the last four years, research is perceived as separate from nursing - an optional extra for those who would choose to do so. These learners are experienced registered nurses with a high percentage of unit managers in the group, but research is seen as irrelevant to their daily activities. On-going research has shown that the learners evaluate their own ability and willingness to do research at the beginning of a year programme, at 3-3,5 on a scale that range from $0-10(0=$ not willing/able and $10=$ completely willing / able) (Zeelie, 2002:182). The research programme is a core module in the curriculum and less than $10 \%$ of the learners would have chosen to do research if it was not compulsory.

\section{Integration strategy}

In the undergraduate baccalaureate programme, research is seen as an integral part of the programme and is introduced from the first year through to the fourth year. Tenets of the programme rest on the following aspects:

- The vision of the institution of higher education is to be a world-class University of Technology that provides innovative leaders and knowledge for prosperity in Southern Africa and the mission statement includes commitment to promoting innovative research

- The outcomes stated for the baccalaureate nursing programme include analysis, interpretation and utilisation of a range of research findings in scientific nursing and midwifery care as well as the development of a research protocol in a given context.

- $\quad$ Learners should feel competent in developing a research protocol, implementing the research and writing a scientific report.

- The theoretical aspect of research is taught as an independent subject, building progressively through the four years.

- $\quad$ Scientific writing is a specific focus from the first year of study. As the majority of learners are taught in their second language, scientific writing in English is a skill that must be developed.

- Research experiential learning is planned pro-actively in conjunction with the nursing experiential learning of the learners. Research is learned by repetition. The skills needed for doing research has been identified and the learners are given the opportunity to learn research through practical experience.

- $\quad$ For learning to be meaningful, it has to have immediate application for the student.

Research should be 'normal' part of everyday life as a professional nurse. Learners are guided through the process of seeing their clinical practise as a source of research problems. Integration and practical experience during clinical practise are pivotal in achieving this goal.

The question to be addressed was how this situation can be changed, how can the teaching of research be adapted to have the desired end result, namely registered nurses who are knowledgeable consumers of research and productive scholars of nursing. The case study presented in this article, reports on using scheduled nursing experiential learning as research experience in the second year of a four-year baccalaureate programme.

\section{A case study}

School health nursing is part of the second year nursing experiential learning. The aim of school heath services is to provide an appropriate service in order to achieve the best possible level of health (mental, physical, and social well being, current and future) for children of school age and to enable children to derive full benefit from their education (Adnams \& Wagstaff, 2001:287). Screening procedures include growth monitoring, vision testing and hearing. Screening is also done for various disorders such as 


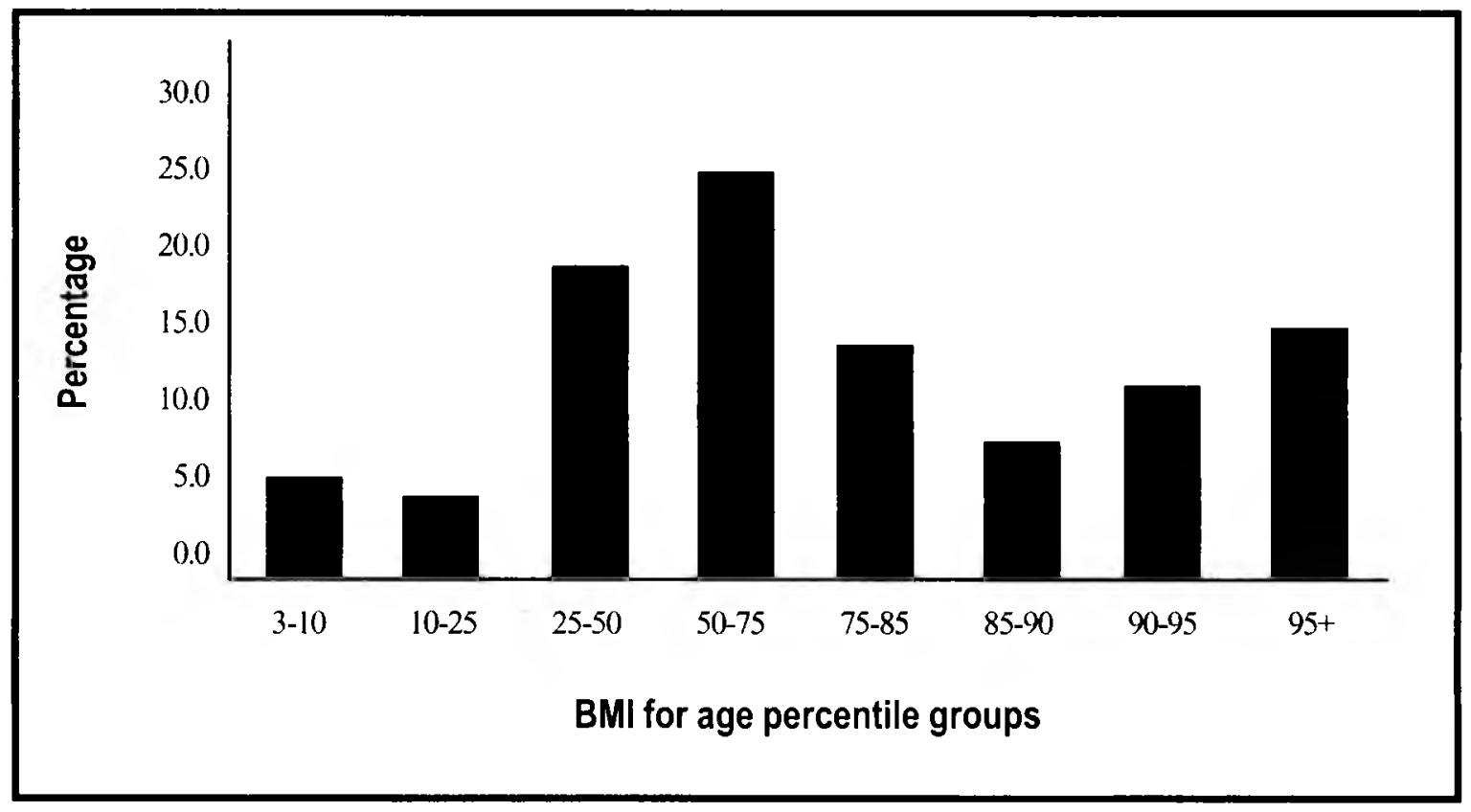

skin infections, orthopaedic conditions, dental caries, heart murmurs, ear infections, hernias, and undescended testes.

According to Smetherham (online), one in 10 children in South Africa has a chronic illness with asthma one of the cost common of these. Children under the age of five are seen at primary care clinics due to the need for immunisations, but this is not the case for children six to 18. These children only visit a clinic if they are desperately ill and as such are largely a missed opportunity to improve the child's health should there be a problem.

The school participating in the nursing learners' experiential learning is a school catering for black children from affluent families and the school is visited every year during the first semester. The parents gave written consent for the children to participate in the programme. The aim of the school health programme is to equip the learners to examine healthy children and diagnose specific health risks in the children. The learners do a physical examination of the children under supervision of their lecturer. This examination includes a physical examination, weight and height measurement and an eye test using the Snellen chart. The data is recorded on standard pre-printed school medical forms. Any problem identified is referred to a medical doctor who is part of the educational team and if a problem is diagnosed, a letter written to the parents.
As part of the learners' experiential learning during school health nursing, they must prepare and present a health cducation intervention for the children. Using school health nursing as research experiential learning entails the following:

- Preparation before the experiential learning

- Introducing the concepts: research question/statement, research methods, population, data gathering, field worker and ethics of research in the research lecture.

- Developing a research question in conjunction with the learners, namely: Which health risks are prevalent in the specific black school community?

- Choose a research method to gather the data. In this case, a survey was chosen using all the children in the school as the population.

- $\quad$ No data-gathering instrument had to be developed, as the school medical form is a standard form for school health nursing. Developing research data gathering instruments is a focus of the third year.

- $\quad$ Learners are taught regarding the importance of data gathering and being meticulous in completing the forms correctly.

- The lecturer obtains, with the assistance of the school management, permission from the parents for their children to participate in the school health programme.

Data gathering

The learners examine all the children with their nursing lecturer and complete the forms. The school is visited on various occasions.

Data analysis

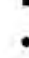

- The forms are brought to the department and the data transferred to an Excel spreadsheet by the lecturers.

- The analysis of the data is done through the institution's statistical support service. Coding of data and descriptive data analysis is a focus of the third year of study. In the second year, the learners do not analyse the data themselves.

- Using the research results in the follow-up nursing experiential learning

- Data are pooled and the children therefore remain anonymous.

The results of the survey are discussed with the learners and real problems identified in the survey are used for the student's health education intervention. In this case, obesity and dental carries were problems that needed to be addressed.

Scientific writing are embedded again with the 
learners writing a report on the school health survey.

To emphasise the usefulness of the survey in teaching students about research, the results of the survey are discussed in class.

\section{Results of the school}

\section{survey}

\section{Biography}

The children's $(n=96)$ ages ranged between five to thirteen years; $57.3 \%$ were males and $42.7 \%$ females. All the children's general health appearance was good, except for one child who was described as obviously uncared for as evident by bedraggled clothes with buttons missing, lack of body hygiene with dirty skin, nails, teeth and ears and an unpleasant body odour. He had an obvious umbilical hernia, which was reported the previous year and not attended to.

\section{Obesity}

For growth monitoring, The Body Mass Index (BMI) for age (National Center for Chronic Disease Prevention and Health Promotion: online) was used to convert the height and weight measurement to an internationally accepted method in order to determine whether a child is
Table 2 : Underweight, normal, over weight and obese categories $(n=96)$

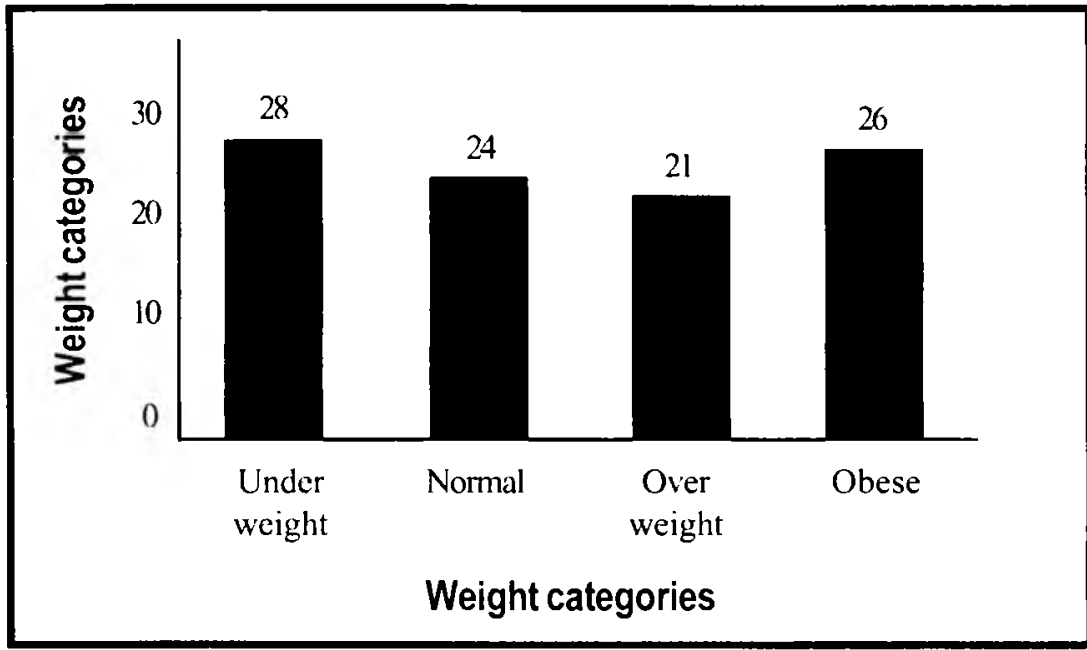

below or above what is expected of him or her at a specific age. The BMI-for-age of the school children is presented in Table 1.

The importance of the table is more evident if the BMI is grouped for under weight, overweight and obesity as is shown in Table 2. The classifications for the weight categories using the BMI-forage percentiles are as follows:

$$
\begin{aligned}
& \text { - 3-50: under weight } \\
& \text { - } \quad \text { 50-75: normal } \\
& \text { - 75-90: overweight }
\end{aligned}
$$

$90+$ : obese

The problem regarding the weight of the children is that $76 \%(n=75)$ of the children are malnourished. Of these, $63 \%(n=47)$ are either overweight or already obese. In the obese group $(n=26), 14$ of the 26 children are over the 95 th percentile of the BMI-for-age.

The underweight category constitutes $38 \%$ of the children in the school. If this category is investigated further, $19 \%$ is below the $10^{\text {th }}$ percentile, $15 \%$ between $10-25$ and the rest - $67 \%$, falls in the $25-$

Table 3 : Age by BMI-for-age perentile groups ( $n=96$ )

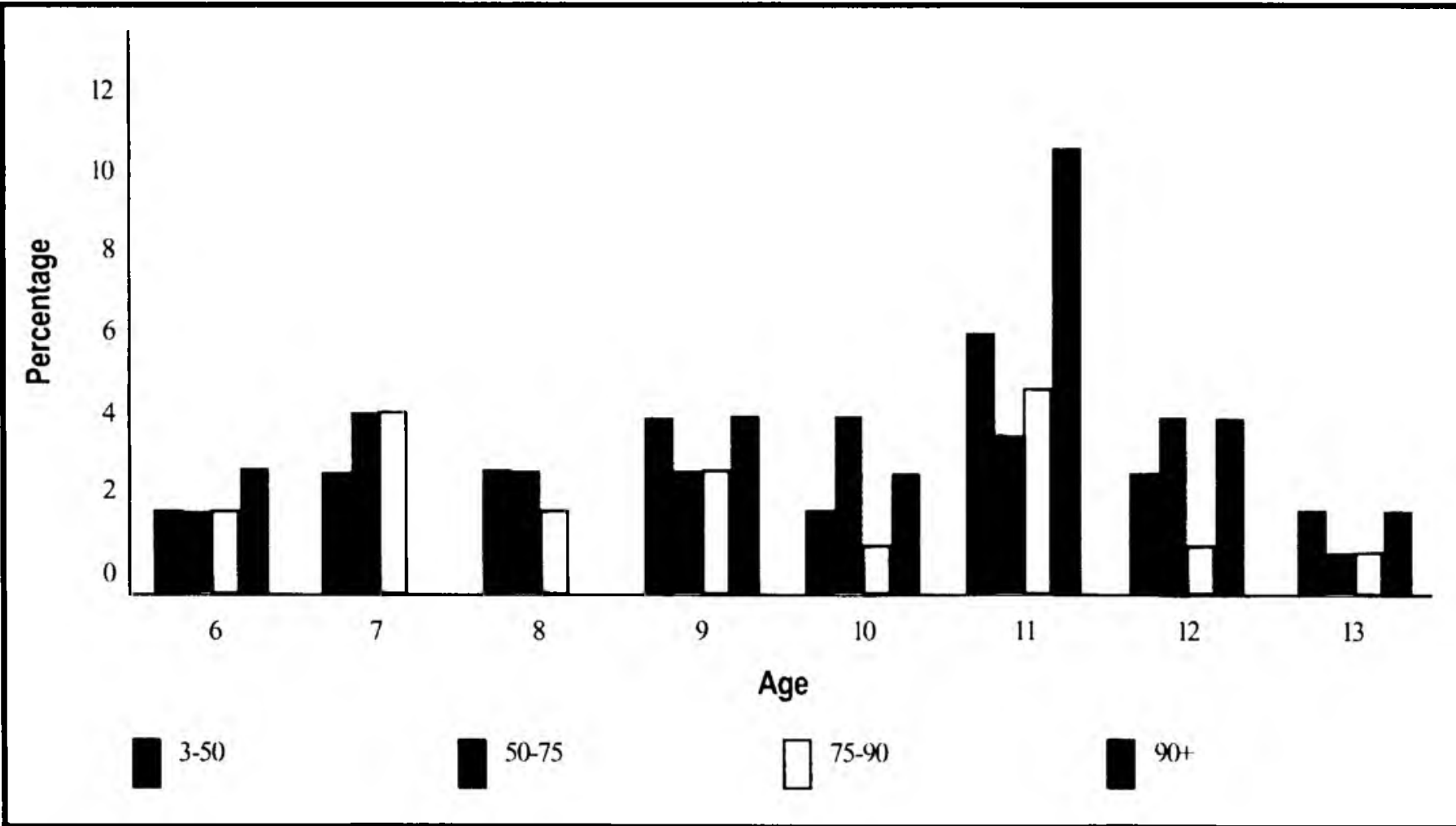


50 th percentile group. There are thus nine children in the school below the $25^{\text {th }}$ percentile of the BMl-for-age. For a child, under nutrition is an equally serious problem than obesity. According to Salooje and Pettifor (2001:118), under nutrition is frequently part of a vicious cycle that includes poverty and infection. The three factors are interlinked so that each contributes to the presence and permanence of the other.

Another trend that became evident when the BMI-forage is cross tabulated with age is shown in Table 3.

From Table 3 it is clear that the obese children are more frequent from age 9-13 with a peak at 11 years. Childhood obesity is rapidly emerging as a global epidemic that will have profound public health consequences as overweight children becomes overweight adults. These children are also at an increased risk for co-morbid conditions such as orthopaedic, pulmonary, gastrointestinal, and endocrine conditions.

It is important that the health intervention regarding weight control/nutrition is of such a quality that the children would understand the importance thereof, without being put under too much pressure to reduce weight. To achieve such an outcome is in itself very challenging and would not succeed without parental commitment.

\section{Dental caries}

The second most important problem identified from the data was dental caries. Dental caries was found in $37.5 \%(n=36)$ of the group. The number of affected teeth per child varied as shown in Table 4.

Having three or more teeth affected would mean that $41 \%$ of the children with dental caries have a serious problem. It should be noted that two children had five and another two children had six affected teeth each. If the dental problem is cross tabulated with age (Table 5), it can be seen that the highest prevalence of dental caries is in the 9-11 age group with a peak at 11 years. This correlates with the overweight/obesity prevalence in the group. There is however, a higher incidence of dental caries in the younger ages as compared to overweight/obesity.

\section{Other health risks identified}

The other health risks that were identified are presented in Table 6.

From Table 6, several other health problems existed among the school population. Most worrying might be the

Table 5 : Dental caries per age $(n=36)$

\section{Dental caries per age}

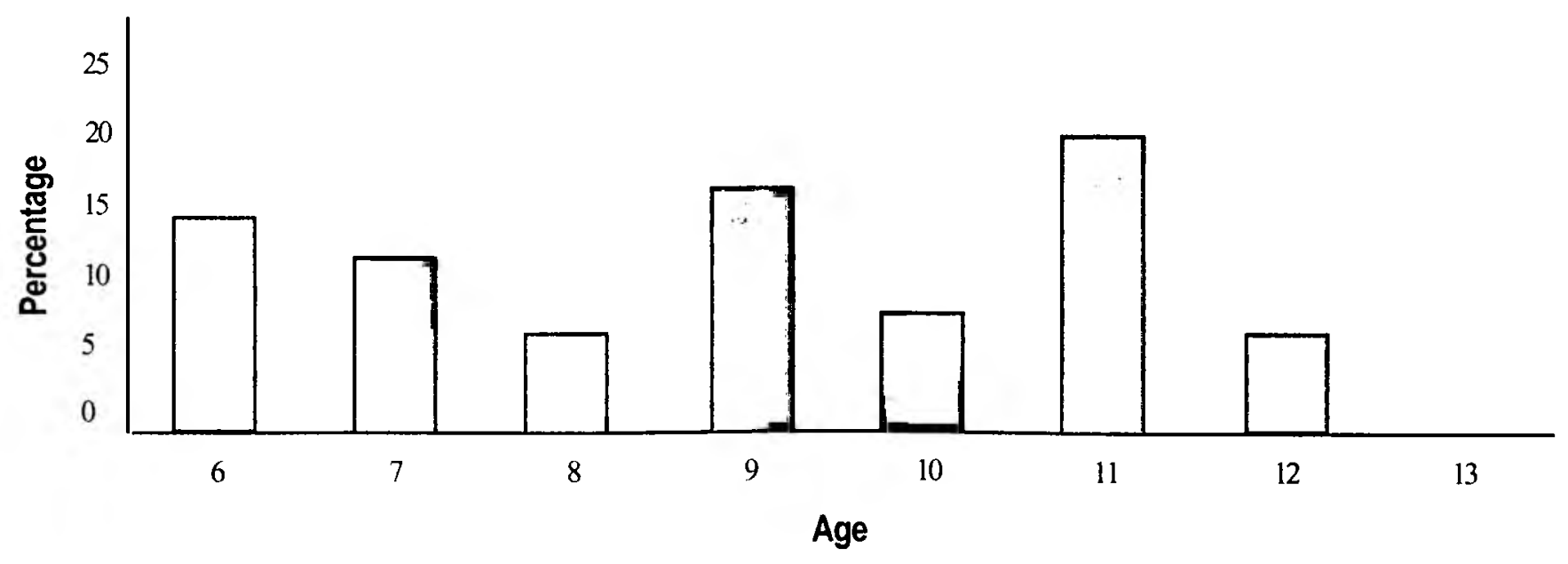


Table 6 : Other health risks identified in the school survey $(n=96)$

\begin{tabular}{|c|c|c|c|}
\hline & Other health risks & $\mathbf{n}$ & Percentage \\
\hline 1 & Poor vision left or right eye & 14 & $14 \%$ \\
\hline 2 & $\begin{array}{ll}\text { Ears: } & \\
\text { - } & \text { Wax } \\
\text { - } & \text { Otitis media } \\
\text { - } & \text { Otitis externa }\end{array}$ & $\begin{array}{l}36 \\
3 \\
1\end{array}$ & $\begin{array}{l}38 \% \\
3 \% \\
1 \%\end{array}$ \\
\hline 3 & $\begin{array}{l}\text { Throat: } \\
\text { - } \quad \text { Red } \\
\text { - } \quad \text { Tonsillitis }\end{array}$ & $\begin{array}{l}4 \\
11\end{array}$ & $\begin{array}{l}4 \% \\
11 \%\end{array}$ \\
\hline 4 & Enlarged lymph nodes & 6 & $6 \%$ \\
\hline 5 & $\begin{array}{ll}\text { Skin: } & \\
\text { - } & \text { Scabies } \\
\text { - } & \text { Ringworm }\end{array}$ & $\begin{array}{l}11 \\
3\end{array}$ & $\begin{array}{l}11 \% \\
3 \%\end{array}$ \\
\hline 6 & Anaemia & 3 & $3 \%$ \\
\hline 7 & $\begin{array}{l}\text { Lungs: } \\
\text { - } \quad \text { Wheeze } \\
\bullet \quad \text { Crepitations }\end{array}$ & $\begin{array}{l}1 \\
2\end{array}$ & $\begin{array}{l}1 \% \\
2 \%\end{array}$ \\
\hline 8 & Hernia - umbilical & 6 & $6 \%$ \\
\hline 9 & $\begin{array}{l}\text { Genito-urinary: } \\
\text { - } \quad \text { Undescended testes } \\
\text { - } \\
\text { Phimosis }\end{array}$ & $\begin{array}{l}4 \\
2\end{array}$ & $\begin{array}{l}7 \% \\
3 \%\end{array}$ \\
\hline 10 & $\begin{array}{l}\text { Spinal curve: } \\
-\quad \text { Scoliosis } \\
-\quad \text { Kiphosis }\end{array}$ & $\begin{array}{l}2 \\
1\end{array}$ & $\begin{array}{l}2 \% \\
1 \%\end{array}$ \\
\hline
\end{tabular}

four boys who still have undescended testes in primary school. Polsdorfer (1999:online) write that only $3-4 \%$ of full term boys have undescended testes, and half of those complete the journey by the age of three months. Eighty percent of all undescended testes naturally correct themselves during the first year of life. Undescended testes that are not corrected can lead to sterility and an increased risk of testicular cancer. In addition, the phimosis case should be corrected as soon as possible.

Six children had umbilical hernias that have not been corrected surgically. Umbilical hernias are fairly common. Such a hernia is obvious at birth, as it pushes the umbilicus outward. In infants, the defect is not usually treated surgically.
In most cases, by age 3 the umbilical hernia shrinks and closes without treatment. Umbilical hernia repair may be necessary for children if the hernia is incarcerated or strangulated or the defect has not closed by 3 or 4 years of age (MEDLINEplus:online).

Spinal curve defects were also found: two children with scoliosis and one with a kyphosis. These problems represent stable health problems that will not cause an acute problem for the child, but which could affect him or her later in life.

Contagious diseases such scabies and ringworm should be dealt with promptly. Scabies is a contagious disorder of the skin caused by very small, wingless insects or mites called the Human Itch mite or Scabies itch mite Sarcoptes scabiei var. hominis (Hering). The female insect burrows into the skin where she lays 1 - 3 eggs daily. A very small, hard to see, zigzag blister usually marks the trail of the insect as she lays her eggs. Other more obvious symptoms are an intense itching (especially at night) and a red rash that can occur at the area that has been scratched. Scabies is spread by personal contact, e.g., by shaking hands or sleeping together or by close contact with infected articles such as clothing, bedding or towels. It is usually found where people are crowded together or have frequent contact, and is most common among school children, families, roommates, and sexual partners (Facts about Scabies: online).

Ringworm is a contagious fungus infection that can affect the scalp, the body, the feet (athlete's foot), or the nails. People can get Ringworm from direct skin-to-skin contact with an infected person or pet or via indirect contact with an object or surface that an infected person or pet has touched. Ringworm can be treated with fungus-killing medicine (Ringworm: online).

More acute problems that could influence the child schoolwork were ear and throat problems, respiratory problems, anaemia and enlarged lymph nodes. The children should be referred to a medical practitioner for treatment as soon as possible.

\section{Positive outcomes of the integration strategy}

The most important positive outcome is that the learners participate in the research process as part of their nursing clinical experiential learning. Research is not experienced as an optional extra but as an integral part of nursing. Using the nursing experiential learning as research experiential learning makes the research theory 'alive'. The learners accept research as a tool to be able to nurse effectively. In the school health data, the learners were guided by the data regarding the health intervention and from the data, it is clear that the obesity and dental caries are serious problems in that population.

A question from the students following the research was what the prevalence of these health risks were in South Africa, and what could it be in other schools. 
Thus the learners experienced the need for further investigation and the exposure to research, though at a limited level, stimulated their curiosity. Learners perceived their experiential learning as possible research problems - echoing Wilson's statement that the dailiness of nursing practice offers an important source of clinically relevant research problems (Wilson, 1991:280).

Another important aspect is that nurse educators of diverse disciplines are joining forces in a most productive way. The educators are seen to be interested in research and actively engaged in research. This aspect is most important to be able to be good role models for the learners. Learners will not develop an interest in research if there are no positive role models available. Wax wrote the following in 1966: 'If nursing is to have enough specialists in research, faculties in baccalaureate and graduate programmes not only must develop a healthy attitude towards it, but must stimulate interest in their students and encourage those with potentialities for research to pursue it.' (Wax, 1966:70).

The research data were of immediate use to the learners. In a small way, the learners made the first step in using research data as the basis of their nursing decisions. Learning about research and implementing research was experienced as meaningful. This positive experience prepares the learners for the research theory and experiential learning of the third year of study.

\section{Conclusion}

Obscuring the traditional lines between nursing and research in the undergraduate programme will produce nursing professionals who are less conscious of this division. If learners could accept that experiential learning is simultaneously nursing and research experiential learning, or actually that nursing and research experiential learning is one concept, much would be gained in the process of producing professional nurses who are knowledgeable consumers of research and productive scholars in nursing.

\section{References}

ADNAMS, CM \& WAGSTAFF, LA 2001. School health. In: Kibel, M.A.\& Wagstaff, L.A. eds. Child health for all: a manual for Southern Africa. Oxford:
Oxford University Press

FACTS about Scabies. S.a. Available at: <http://www.safe2use.com/pests/ scabies/scabies.htm>.

\section{NATIONALCENTRE FOR CHRONIC DISEASE PREVENTIONANDHEALTH PROMOTION 2003. BMI for children and teens. Available at: <http:// www.cdc.gov/nccdphp/dnpa/bmi/bmi- for-age.htm>.}

MEDLINEplus Medical Encyclopedia: Umbilical hernia repair. 2003. <http:// www.nlm.nih.gov/medlineplus/ency/ article/002935.htm>. Accessed 22/8/2003.

POLSDORFER, JR 1999.

Undescended testes. <http:// www.findarticles.com/cf_0/g2601/0014/ $2601001421 / \mathrm{pl} /$ article.jhtml $>$. Accessed $22 / 8 / 2003$.

RINGWORM facts. S.a. Available at: http://www.astdhpphe.org/infect/ ringworm.html. Accessed 22/8/2003.

SALOOJE, H \& PETTIFOR, JM 2001. In: Kibel MA \& Wagstaff LA 2001. Child health for all: a manual for Southem Africa. $3^{\text {rd }}$ ed. Cape Town: Oxford University Press

SMETHERHAM, J 2003. School health policy to spot kids needing care. Available at: http://news.hst.org.za/ view.php3?id=20030729.

THORPE, R \& SMUTKO, PW 1998. Introducing $\mathrm{ADN}$ students to nursing research. Nurse Educator. 23(4):13-15.

WAX, J 1966. Attitude of nursing students towards research. Nursing Outlook, April, 70-72.

WILSON, HS 1992. Introducing research in nursing. Redwood city: Addison-Wesley.

WISNESKI, SM 1998. Teaching nursing research to minority students. ABNF Journal. 9(6): 135-6.

ZEELIE, SCD 2002. A self-evaluation system for quality assurance in nursing research. D Tech thesis, Technikon Pretoria, Pretoria. 